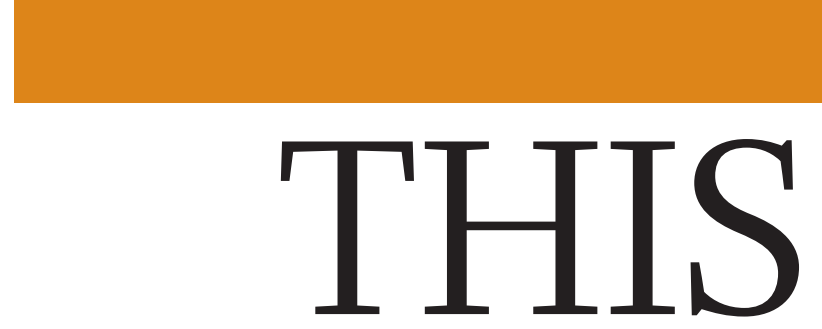

\title{
EDITORIALS
}

GUNS New hope for

firearms research in

United States $\mathbf{p . 4 3 6}$
WORLD VIEW Discuss

climate change in the

present tense $\mathbf{p . 4 3 7}$
GOBBY GLUE Sticky saliva

the secret to terrific

tongues $\mathbf{p . 4 3 8}$

\section{Way of the dragon}

\section{To boost its research quality and innovation, China must strengthen its scientific foundations and let researchers - not policymakers - set the agenda for innovation and discovery.}

$\mathrm{T}$ There is increasing excitement over China's scientific rise. The nation has more researchers than any other country and it is rapidly catching up with the United States in the number of scientific papers published. But there are lingering questions - both within China and outside - about the quality and inventiveness of science coming out of the country.

Concerns over science in China go to the very top. Xi Jinping, China's leader, offered a particularly harsh assessment late last month at a meeting of the country's leading scientific academies. He went so far as to say "the country's S\&T foundation remains weak".

$\mathrm{Xi}$ has a point. Many of the inventions that gave rise to some of the most important scientific work in China - CRISPR-Cas9 geneediting tools among them - are the products of colleagues overseas. $\mathrm{Xi}$ put it like this: "The situation, in which our country is under others' control in core technologies of key fields, has not changed fundamentally."

From that angle, China still looks like a nation of large-scale implementers. Take an idea, especially one that requires scale, and China is there to jump on it. That is not a bad place to be - the genome-sequencing giant BGI and a new generation of sequencing rivals are a clear sign of just how productive scale can be. But that is application, not the kind of breakthrough that Xi seeks.

That's why the country's first scientific Nobel prize, awarded last October to Tu Youyou for her role in developing the antimalarial drug artemisinin, provoked pride but also soul-searching. It was a discovery from a bygone era, not a product of the current research structure - and many wonder whether today's system will yield any big discoveries.

In a special issue this week, Nature looks at China's potential and the obstacles it faces (see www.nature.com/chinafocus). Xi told the meeting that "scientists should be allowed to freely explore and test the bold hypotheses they put forward". He encouraged the development of a system in which science policy is created by scientists, rather than at the whim of officials, and alluded to experts who "should no longer have to follow their superiors' orders".

If anyone can break the bureaucrats' hold on scientific policymaking, it is $\mathrm{Xi}$, who has emerged as China's strongest leader in decades. He has already taken on, and taken down, numerous political foes. And yet, as China implements its latest five-year plan and overhauls its major funding mechanisms, there is reason to wonder how much things will change.

$\mathrm{Xi}$ couches much of his support for science as the quest for translatable results. Scientists should, he says, solve urgent economic and industrial prob-

lems. Support for technology firms is a high priority. These are fine

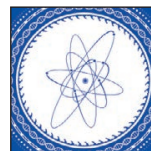
SCIENCE IN CHINA A Nature collection nature.com/chinafocus objectives, but they suggest continued top-down policymaking. The balance between encouraging basic research and demanding technological output must be guarded closely, or scientists will be pressured to do only translatable research and China will tread on the freedom of scientific pursuit that Xi holds is essential.

Although Xi seems to understand the scientific thirst for independence and freedom, the ongoing question is whether China
"Truly

pioneering

science is to be cultivated, not commandeered.' will offer that. This includes freedom to use tools such as Google Scholar.

$\mathrm{Xi}$ faces some of the greatest battles of China's recent past: military tussles in the South China Sea have raised the political stakes abroad, economists talk of a dangerous slowdown, and environmental problems are frustrating citizens at home and threatening the country's international stature. $\mathrm{Xi}$ vows to raise spending on science, but it would be a mistake to think that increasing spending on research and development will solve all the issues of the homeland, make food and drugs safe, resolve the problem of an ageing population and get rid of the disparities between urban and rural China.

At the meeting, Xi said: "Currently, the state needs the strategic support of science and technology more urgently than any other time in the past." But truly pioneering science is to be cultivated, not commandeered. How well that distinction is maintained will determine much of what lies ahead.

\section{Data sharing}

\section{Pooling clinical details helps doctors to diagnose} rare diseases - but more sharing is needed.

$\mathrm{W}$ hen doctors in Ottawa saw a child with an unusual developmental disorder last year, they were stumped. Their patient had an abnormally small head and face and had been slow to develop. They sequenced the child's genome hoping to find a genetic explanation, but came up with too many possible candidate genes to pinpoint a likely culprit. This still happens a lot in medicine: people with rare problems go undiagnosed. And that's one reason behind a big push in science in recent years - the pooling and sharing of clinically relevant information.

In the Ottawa case, the doctors got lucky. They were able to search a database that contained information about other patients with undiagnosed diseases, and when they did so they found a second person with similar symptoms - and an identical mutation in one 